\title{
Deterrent Measures and Cheating Behaviour of Accounting Undergraduates in Tertiary Institutions in Lagos Nigeria
}

\author{
Semiu Babatunde Adeyemi (Corresponding author) \\ Department of Accounting, University of Lagos \\ Lagos, Nigeria
}

Tel: 234-80-3507-1047Ｅ-mail: sbaadeyemi@yahoo.co.uk

Samuel Olunlade Adelaja

Department of Accounting, University of Lagos

Lagos, Nigeria

Tel: 234-80-2343-0671 E-mail: adelaja2007@yahoo.co.uk

Received: June 20, 2011

doi:10.5539/ijbm.v6n12p195
Accepted: July 18, $2011 \quad$ Published: December 1, 2011

URL: http://dx.doi.org/10.5539/ijbm.v6n12p195

\begin{abstract}
Accountants serve in management positions where they influence the preparation of financial statements or are actually involved in their preparation. Also the public relies on accountants to attest to the truth and fairness of financial statements as external auditors. However, the unfolding events all over the world in the recent past and currently, have put the accounting profession on the defence as regards members' integrity, honesty and objectivity in the discharge of their responsibilities. High profile corporate failures that have led to the credibility crisis in financial reporting are reported in many parts of the world. In order to address the credibility crisis in financial reporting, it is necessary, at least partly, to revisit the framework within which professional accountants are produced with a view to attacking ethical violations, most especially cheating behaviour, which could lead to future ethical problems. The accounting profession draws substantial portion of its prospective professional accountants from the accounting students of tertiary institutions, whose ethical disposition while in the university or polytechnic could affect their future professional career if not properly directed. The aim of this study is to find out the extent of the participation of the Accounting Students in different forms of cheating, their reasons for cheating and what they perceived as factors that could curb the practice of cheating. The study adopted survey research method and the instrument of survey was the research questionnaire. The study found that some Accounting Students were involved in cheating in their academic activities in tertiary institutions in Lagos State. It is also found that some deterrent measures could be effective in curbing cheating behaviour, if properly applied.
\end{abstract}

Keywords: Accounting students, Nigeria, Cheating, Ethics, Credibility, Financial statements

\section{Introduction}

\subsection{Background to the Study}

Financial reporting has historically been one of the main ways in which a company provides information to its shareholders, prospective investors and other users. The integrity, efficiency and growth of a country's capital market rely heavily on credible financial information. Accountants are, in many ways, connected with financial reporting. Accountants serve in management positions where they influence the preparation of financial statements or are actually involved in their preparation. Also, the public relies on accountants to attest to the truth and fairness of financial statements as external auditors.

Sometimes accountants are relied upon to evaluate investments, prepare tax returns and render other services involving trust. In discharging these responsibilities, it is essential for the professional accountants to accept and observe ethical principles established by law or rules of their profession to ensure that their duties are creditably discharged. The society has high expectations of the accountancy profession. It is, therefore, important for the professional accountant to display high integrity, honesty and objectivity in rendering his professional service.

However, the unfolding events all over the world in the recent past and currently, have put the accounting profession on the defence as regards members' integrity, honesty and objectivity in the discharge of their 
responsibilities. High profile corporate failures that have led to the credibility crisis in financial reporting are reported in many parts of the world. In the United Kingdom, there were cases of BCCI and Polly Peek. In France, there was the case of Credit Lyonnais; Germany recorded the case of Metalgeselschaft and Schneider; Australia recorded the case of Spedley Securities and Tricontinental while in the United States of America, there were the cases of Cendant, Sunbeam, Waste Management, Woldcom, Global Crossing, Tyco and Enron Corporation (IFAC 2008). Nigeria has also witnessed cases of corporate scandals involving African Petroleum, Cadbury Nigeria Plc, Lever Brothers and many banks, which have either been liquidated or restructured with the top management team sacked and new management team put in place by the Central Bank of Nigeria. The problems that led to the collapse of some of these institutions have been traced to financial reporting failures partly attributable to unethical behaviours on the part of the accountants who prepared the financial statements and the auditors who rendered unqualified report just before the corporate failures. The fraudulent financial reporting in Enron Corporation that led to the collapse of Arthur Anderson auditing firm, is a case in point.

In order to address the credibility crisis in financial reporting, it is necessary to revisit the framework within which professional accountants are produced with a view to attacking ethical violations that could lead to future ethical problems. This is because the accounting profession draws substantial portion of its prospective professional accountants from the accounting students of tertiary institutions, whose ethical disposition while in school could affect their future professional career if not properly directed. For the purpose of this study, universities and polytechnics constitute tertiary institutions.

\subsection{Statement of Problem}

Research has established that academic dishonesty by way of cheating is relatively high among college and university students (Baird 1980; Green and Saxe 1997; Meade 1992; Brown and Abramson 1999; Brown and McInerney 2001. Eromosele (2005) indicated that examination malpractices (cheating) in Nigeria have "attained a frightening proportion. It is sophisticated and institutionalised". This observation is not far from the truth. In the Departments of Accounting of tertiary institutions where this study was carried out, there was no semester examination, in the recent past, where one form of cheating or the other was not recorded. Examinations Malpractices Committees usually met during and after semester examinations to deal with cases of examination malpractices. In many of the cases, the accounting students were found guilty of cheating. A person who cheats in one environment is likely to cheat in another. Nonis and Swift (2001) found a strong correlation between cheating at school and cheating at work.

The International Federation of Accountants (IFAC, 2008), through its International Accounting Education Standards Board is of the opinion that educators and professional bodies need to distinguish between teaching students about professional values, ethics and attitudes and developing and instilling ethical behaviour in the students. One way in which educational institutions can do this is to find out the extent of participation of the accounting students in different forms of cheating, their reasons for cheating and what they perceived as factors that could moderate or neutralize their intention and practice of cheating.

\subsection{Purpose of Study}

The purposes of this research study are to evaluate:

(i) the extent of participation of the Accounting students in cheating;

(ii) the perception of the Accounting students on the reason that could motivate cheating behaviour among them; and

(iii) the perception of the Accounting students on the effectiveness of deterrent factors in curbing or reducing cheating behaviour.

\subsection{Research Questions}

The following research questions guided the researcher in carrying out this study:

(i) How widespread is cheating behaviour among the Accounting students in tertiary institutions in Lagos State?

(ii) Why do the Accounting students engage in cheating?

(iii) Can cheating behaviour in the Accounting students be curbed or reduced through application of deterrent measures?

\subsection{Research Hypothesis}

The research hypothesis formulated for this study, as stated in the Null form, is as follows:

Null Hypothesis: The application of deterrent measures is not effective in curbing cheating behaviour among Accounting Students in tertiary institution in Lagos State. 


\subsection{Significance of Study}

This study is important because its outcome can lead to the strengthening of the ethical content of the training programmes of Accounting students who are likely to become professional accountants. Good ethical orientation inculcated in the Accounting students in the tertiary institutions could promote ethical excellence in the work place thus enhancing the credibility of the financial reporting processes.

\section{Literature Review}

\subsection{Studies on the Extent of Cheating}

Research has shown that cheating behaviour among students in the United States of America (USA) was widespread and increasing. Bowers (1964) cited in McCabe et al. (2001), published the first large-scale study of cheating in institutions of higher learning. The study covered more than 5,000 students in a sample of 99 U.S. Colleges and universities and found that $75 \%$ of the respondents had engaged in one or more incidents of academic dishonesty. The study was replicated by McCabe and Trevino (1997) in some of the schools, which formed the sample frame of Bowers' study, and a modest increase was observed in overall cheating while significant increases were found in tests and examination cheatings.

\subsection{Studies on the Influence of Variable Factors on Cheating}

Many aspects of academic misconduct among students of tertiary institutions, most especially cheating behaviour, have been a subject of research over the years in many parts of the world. Cheating among accounting students who are likely to be future professional accountants has been a subject of interest to researchers. Smith et al. (2002) studied cheating behaviour among 606 accounting students and examined the influence of different variables on the likelihood of future cheating. Such variables included demographic and attitudinal characteristics, the tendency to neutralize cheating behaviours, the impact of deterrent factors and reported prior cheating behaviour. The study found that deterrent factors, prior cheating and the degree to which one neutralized prior cheating were likely to influence cheating behaviour. The finding of the researchers, that prior cheating may have influence on future cheating, is in accord with the findings of Davis and Ludvigson (1995), which indicated that cheating in the past, is a predictor of future cheating.

\subsection{Studies on the Influence of Contextual and Individual Factors}

Some of the studies on student cheating behaviour have focused on the influence of contextual factors on the decision to cheat while a sizeable number of others have examined the role of individual factors. Researches have suggested that contextual factors that influenced cheating by students include: faculty responses to cheating sanction threats, social learning and honour codes (Jendrek, 1989; Tittle and Rowe, 1973; Michael \& Miethe, 1989).

Researches have also shown that individual factors that may have significant influence on cheating behaviour include: gender, age, Grade Point Average, work ethic, competitive achievement striving and self-esteem (Eisenberger and Shank, 1985; Ward 1986; Ward and Beck, 1990). Crown and Spiller (1998) who reported on eighteen prior studies which examined gender differences in cheating behaviour indicated that six studies found that males cheated significantly more than females, two studies reported that females cheated more than males, while ten studies submitted that there was no significant difference found.

Grade Point Average (GPA) is another factor that could be related to cheating. The majority of the previous studies have reported that students with low GPA are more likely to cheat (Crown and Spiller, 1998; Whitley 1998; Smith et al. 2002). Atmeh and Al-Khadash (2008), in a study of 307 accounting students, found that female students with a high GPA and final year students may be less likely to cheat and that there are significant relationships between deterrent factors, neutralization and likelihood to cheat. Ajibolade (2008), using various forms of academic misconduct to evaluate the perception of ethical behaviour of future Nigerian accounting professionals, reported that the beginning students (lower level) have higher ethical perception scores than the final year (higher level) students. The implication of this finding is that accounting education in Nigeria has no positive impact on the ethical orientation of future professional accountants. Although some studies have established correlations between individual factor variables and cheating, the research findings do not appear to be conclusive in establishing the importance of such variables in explaining the tendency to cheat by students in examinations or class tests. The result of gender differences in influencing cheating behaviour has been inconclusive. Many studies have reported that males cheated more than females (Ward \& Beck 1990; Lobel 1993), while other studies such as Leming (1980) have found females exhibiting more cheating tendencies than males. There are yet other studies that talked of no statistically significant differences between male and female ethical orientation as far as cheating behaviour is concerned (Haines et al. 1986). 


\subsection{Studies on the Influence of Social-academic Environment}

Academic misconducts in terms of cheating can be influenced by social-academic environment. Kerkvliet and Sigmund (1999) in their study found that increasing the distance between students in an examination has some effect on academic misconduct. Bowers (1964), indicated that it has been found that student cheating rates rise significantly, the more the students spend on extra-curricular activities of playing cards watching television or drinking with friends. McCabe and Trevino (1997) found a strong correlation between fraternity membership and academic misconduct.

Psychologists have noted that all people tend to follow the norms of their peer group, which, in the case of academic environment, would include norms about academic dishonesty (Power et al., 1989). The implication of this is that the students who believe that their peers disapprove cheating behaviour are less likely to cheat while students are likely to engage in cheating behaviour when they perceive that their peers approved cheating. An institution's academic integrity climate could be an important mediating variable in student cheating. Research has shown that schools with honour codes reported less cheating than those with no honour codes (McCabe and Trevino, 2002). However, Roig (2006) was of the view that cheating is primarily the result of the way the students view education. He was of the opinion, and this is in accord with the view of other scholars, that students see college education mainly as certification process whose primary purpose is not to learn about oneself and the world, but rather to increase the students' chances of getting a better paying job after leaving school.

\section{Methodology}

\subsection{Research Design}

This study adopted a survey research method, using questionnaire as the data collection instrument. Confidential self-report surveys about mild forms of deviance among individuals have been judged to be methodologically valid and reliable (Clark and Tifft, 1966). Surveys permit researchers in academic misconduct to explore and evaluate the effectiveness of prevention and deterrence measures, as seen from the perspectives of the cheaters and non-cheaters (Hollinger and Lanza-Kaduce, 2009).

\subsection{Study Population and Sample}

The population for this study is made up of the students of the Department of Accounting registered in the 2nd semester of 2009/2010 academic session in two universities and two polytechnics in Lagos State. A study sample size of 600 was drawn from a total population of 2069 students of various levels (100-400) using systematic random sampling techniques based on serially numbered class lists. The polytechnic students are made of the National Diploma (ND) classes and Higher National Diploma (HND) classes. ND year 1 is regarded as 100-level while ND year 2 is regarded as 200 level students. HND year 1 is 300 -level while HND year 2 is regarded as 400-level. A total of 543 copies of the questionnaire were completed and returned, out of which 519 were found usable. The details of the sample are as shown in Table 1.

\subsection{Data Collection}

The survey questionnaire designed for data collection for this study was structured into four sections. Section one was based on the demographic data of respondents while section two was aimed at getting the perception of the respondents on the possible reasons for cheating behaviour. Section three of the questionnaire was aimed at seeking the perception of the respondents on the effectiveness of the suggested deterrent measures in curbing cheating and section four was based on respondents' self-reported participation in cheating behaviour. The respondents were required to indicate their extent of agreement with or participation in the issues raised, using a five-point Likert-type response scale. In the administration of the questionnaire, anonymity was guaranteed and as such, the demographic data requested were gender, level of study and cumulative point average.

The content validity of the survey instrument was examined by two academics that have considerable experience in accounting education after which a slight modification was done. The internal consistency of the instrument was determined using 30 Accounting students of various levels in the Departments of Accounting in tertiary institutions in Lagos State. The calculated coefficient alpha reliability for the entire instrument was 0.73 . This figure suggests that the instrument was suitable to measure the variables of interest of the study.

\section{Data analysis and Interpretation}

\subsection{Demographic Data}

As regards demographic data, Table 2 shows that $52 \%$ of the respondents were male while $48 \%$ were female. The respondents in each level of study are as contained in Table 3 while the respondents' cumulative grade point average frequency distribution is as shown in Table 4 and it shows that 174 respondents (33.5) were in the CGPA class of $2.40-3.49$ ( $2^{\text {nd }}$ class lower $)$ while 168 respondents were in the CGPA class of $3.50-3.49$ ( $2^{\text {nd }}$ class upper $)$ 129 respondents were in the CGPA class below 2.4. 


\subsection{Analysis Based on Research Questions}

The first research question seeks to find out the extent of participation of the Accounting students in cheating. Table 5 shows the frequency distribution of the responses of the respondents on the extent of participation in one form of cheating or the other. The respondents were required to use a 5-point rating scale ranging from 1 for "hate participation" to 5 for "strongly participated". For ease of analysis and interpretation, the responses of "hate participation" and "didn't participate" were summed up and labeled "non-participation" while responses under "participated" and "strongly participated" were summed up and labeled "participated".

Table 5, which is generated from self-reported participation information supplied by the respondents, confirms the level of cheating among Accounting students. For example, while $35.80 \%$ of the respondents agreed to have participated in copying other students' work in an examination, $59.54 \%$ of the respondents agreed to have asked for answers to a question from someone during an examination. This situation needs to be checked with appropriate measures in order to reverse the trend and strengthen the culture of integrity on which the profession of accounting is built.

The second research question is on the reasons that prompt Accounting students to cheat. A number of reasons have been suggested in the literature and these form the basis of the questionnaire in that respect (Atmeh and Al-khadash 2008). It is important to know the reasons why cheating takes place in order to know the steps that could be taken to discourage it. The respondents were required to indicate the extent to which they agreed with the suggested reasons that could be responsible for cheating behaviour among students, using a 5-point rating scale ranging from 1 for "Strongly Disagree" to 5 for "Strongly Agreed". For the purpose of data interpretation, a mean score which is greater than 3 is regarded as a general agreement by the respondents that the suggested reason could be responsible for cheating behaviour among accounting students while a score of 3 and below is regarded as non-agreement. Table 6 presents the mean responses of the respondents on the reasons for cheating.

The mean responses shown in table 6 indicate that some of the main reasons why students cheat include:

1) pressure to have good grade in order to have better opportunity for employment (mean of 4.44), which is rated as having the highest strength of inducing cheating.

2) assigning too much material to be read by the Lecturer as if the course is the only one to be taken by the student (mean of 3.85).

3) danger of losing one's studentship due to previous low grade (mean of 3.81). This means that when the students CGPA is low the likelihood of cheating is high if giving that opportunity; and

4) leaving the examination room by the invigilator to phone or talk to someone (mean of 3.60).

\subsection{Test of Hypothesis}

In order to answer the third research question on the effectiveness of deterrent measures in curbing cheating behaviour among Accounting students, the null hypothesis formulated: The application of deterrent measures is not effective in curbing cheating behaviour among Accounting students in tertiary institutions in Lagos was tested. The statistical tool used in testing this hypothesis is the chi-square test of relationship for each of the deterrent measures suggested. Table 7 presents the test statistics.

The decision rule for this analysis is to accept the null hypothesis if the calculated chi-square is less than the table value of chi-square. The null hypothesis is rejected otherwise. The table value of chi-square at 4 degrees of freedom at $95 \%$ level of confidence is 9.49 . Each of the deterrent measures has a calculated chi-square value that is greater than the table value of 9.49. Therefore, the null hypothesis in respect of each deterrent measure is rejected and the alternative hypothesis is accepted. Our finding therefore is that the deterrent measures are effective in checking cheating behaviour. It could be seen in table 7 that the relationships are all significant at $5 \%$ level of significance $(\mathrm{p}<0.050)$.

\section{Discussion of Findings}

This study has shown that many prospective graduate accountants engage in one form of cheating or the other in going through training in tertiary institutions, the most prominent of which is asking for answers to questions from someone during an examination. A person who cheats in one environment is likely to cheat in another environment or workplace (Nonis and Swift, 2001). Another important finding of the study is that the pressure to have good grade in order to have good opportunity for employment induces students to cheat. Unless strenuous efforts are made therefore to discourage cheating among accounting students, the integrity of the accounting profession may be eroded and the credibility of financial reporting may be greatly affected.

Yet another important finding of this study is that there are measures that could be intensified to check the practice of cheating among prospective accountants. Such measures, among others, include asking students to put all books and personal belongings away; proper invigilation; ensuring that there is empty seat between one student and 
another; warning students of the consequences of cheating at the start of an examination and prompt disciplinary measures for erring students.

\section{Conclusion}

The profession of accountancy is built on the foundation of integrity and honesty and trustworthiness. In order to continue to build on this solid foundation, efforts must be made by all those involved in the training of prospective accountants, including institutions of higher learning, to direct their ethical orientation towards the standards of the profession. The training institutions cannot afford to be lackadaisical in matters of ethics, else, the future of the profession will be in jeopardy. The study has shown that many Accounting students cheat while going through training. This should not be allowed to continue. All necessary measures should be put in place to discourage cheating by Accounting students.

\section{Recommendations}

In view of the findings of this study, it is recommended that tertiary institutions in the field of Accounting should develop codes of behaviour expected of their students and such codes should be "articles of faith" which must be scrupulously implemented. The codes of behavour must be displayed conspicuously so that students may read them as frequently as possible. Awareness should be created before, during and after examinations on the need for the students to observe the ethical values of their institution and of the profession. Tertiary institutions should introduce Courses in ethics of the profession of accountancy and such Courses must be made compulsory. Deterrent measures must be put in place to discourage cheating behaviour among students.

The society should de-emphasize the grades of certificate and seek for productive knowledge in matters of employment. The present situation where the holders of a class of degree are automatically shut out of competition for job positions would encourage cheating in order to acquire a certificate rather than acquiring knowledge that would be beneficial to the society.

This study is domiciled in a few tertiary institutions of learning and as such its findings must be received with caution. Also this study is merely a test of relationships. The strength of each deterrent measure in checking cheating behaviour is not determined. A multi-campus study of cheating behaviour among Accounting students in Nigerian tertiary institutions is recommended. A study of the strength of the deterrent measures in curbing cheating behaviour is also recommended so as to determine the most effective measure.

\section{References}

Ajibolade, S.O. (2008). A survey of the perception of Ethical Behaviour of future Nigerian Accounting Professionals. The Nigerian Accountant, July/September, 54-59.

Atmeh, M., \& Al-Khadasch, H. (2008). Factors affecting cheating among Accounting Students (using the Theory of Planned Behaviour). Journal of Accounting Business Management, 15, 109-125.

Baird, J.S. (1980). Current Trends in College Cheating. Psychology in the Schools, 17, 515-522. http://dx.doi.org/10.1002/1520-6807(198010)17:4<515::AID-PITS2310170417>3.0.CO;2-3

Boig M. (2006). On the causes of academic dishonesty. The write stuff, 15(4) 120-121.

Bowers, W.J. (1964). Student Dishonesty and its control in Colleges. New York: Bureau of Applied Social Research.

Brown, B.S., \& Abramson, J. (1999). The Academic Ethics of Undergraduate Marketing Majors. Academy of Marketing Studies Journal, 3(1), 62-71.

Brown, B.S., \& McInerney, M. (2001). The Academic Ethics of Business Management Students: A lesson for Professors. The International Journal of Business Disciplines, 11(3), 79-88.

Clark, J.P., \& Tifft, I.I. (1966). Polygraph and interviewing validation of self-reported deviant behaviour. American Sociological Review, 70, 516-523. http://dx.doi.org/10.2307/2090775

Crown, D.R., \& Spiller, M.S. (1998). Learning from the literature on college cheating: a review of empirical research. Journal of Business Ethics, 17, 683-700.

Davis, S.F., \& Ludvison, H.W. (1995). Additional data on academic dishonesty and a proposal for remediation. Teaching of Psychology, April, 119-121. http://dx.doi.org/10.1207/s15328023top2202_6

Eisenberger, R., \& Shank, D.M. (1985). Personal work ethic and effort training affect cheating. Journal of Personality and Social Psychology, 49, 520-528. http://dx.doi.org/10.1037/0022-3514.49.2.520

Eromosele S. E. A. (2005). Continuing Education: Training the menace of Examination Malpractices in Nigeria. [Online] Available: http://www.selfgrowthtest.com (August 1, 2009) 
Haines, V.J., Diekhoft, G.M., LaBeff, E.E., \& Clark, R.E. (1986). College cheating: Immaturity, lack of commitment and the Neutralizing Attitudes. Research in Higher Education, 25, 342-354. http://dx.doi.org/10.1007/BF00992130

Hollinger, R.C., \& Lanza-Kaduce. (2009). Academic dishonesty and the perceived effectiveness of countermeasures: An Empirical Survey of cheating at a major public university. MASPA Journal, 46(4), 587-602. International Federation of Accountants. (2008). Professional Values, Ethics and Attitudes IES 4. [Online] Available: http://www.ifac.org. (February 10, 2011)

Jendrek, M. P. (1989). Faculty Reactions to Academic Dishonesty. Journal of College Student Development, 30, 401-406.

Kerkvliet, J., \& Sigmund, C.L. (1999). Can we control cheating in the classroom. The Journal of Economic Education, 30(4), 331.

Lobel, T.E. (1993). Gender differences in Adolescents' Cheating Behaviour: An International Model. Personality Individual Differences, 14(1), 275-277. http://dx.doi.org/10.1016/0191-8869(93)90204-G

Longman Dictionary of Contemporary English. (1978). $3^{\text {rd }}$ edition, p. 215.

McCabe, D.L., \& Trevino, L.K. (1997). Individual and contextual influences on Academic Dishonesty: A multi-campus investigation. Research in Higher Education, 38(2), 388.

McCabe, D.L., \& Trevino, L.K. (2002). Honesty and Honor Codes. Academic, 99, 37-41.

McCabe, D.L., Trevino, L.K., \& Butterfield, K.D. (2001). Cheating in Academic Institutions: A Decade Research. Ethics of Behaviour, 11(3), 219-232. http://dx.doi.org/10.1207/S15327019EB1103_2

Meade, J. (1992). Cheating: Is Academic Dishonesty par for the Course? Prism, 1(7), 30-32.

Michaels, J.W., \& Miethe, T.D. (1989). Applying Theories of Deviance to Academic Cheating. Social Science Quarterly, 70, 870-885.

Nonis, S., \& Smith C. O. (2001). An Examination of the Relationship between Academic Dishonesty and Workplace Dishonesty: A Multicampus Investigation. Journal of Education for Business, November/December, 69-77. http://dx.doi.org/10.1080/08832320109599052

Power, R., Clark, H., A., \& Krohlberg, L (1989). Lawrence Kohlberg's approach to Moral Education. New York: Columbia University Press.

Smith, K.J., Davy, J.A., Roseberg, D.L., \& Haight, G.T. (2002). A structural modeling investigation of the influence of demographic and attitudinal factors and in-class deterrents on cheating behaviour among accounting majors. Journal of Accounting Education, 20, 45-68. http://dx.doi.org/10.1016/S0748-5751(01)00026-4

Tittle, C.R., \& Rowe, A.R. (1973). Moral Appeal, Sanction, Threat and Deviance: An experimental text. Social Problems, 20, 458-497. http://dx.doi.org/10.1525/sp.1973.20.4.03a00080

Volntley, B.E. (1998). Factors associated with cheating among college students: a review. Research in Higher Education, 39(3), 235-274. http://dx.doi.org/10.1023/A:1018724900565

Ward, D.A. (1986). Self-esteem and Dishonest Behaviour Revisited. Journal of Social Psychology, 126, 709-713. http://dx.doi.org/10.1080/00224545.1986.9713652

Ward, D.A., \& Beck, W.L. (1990). Gender and Dishonesty. Journal of Social Psychology, 130, 333-339. http://dx.doi.org/10.1080/00224545.1990.9924589 
Table 1. Details of Distributed and Returned Questionnaire

\begin{tabular}{|c|c|c|c|}
\hline LEVEL & $\begin{array}{c}\text { DISTRIBUTED } \\
\text { QUESTIONNAIRE }\end{array}$ & $\begin{array}{c}\text { RETURNED } \\
\text { QUESTIONNAIRE }\end{array}$ & USABLE QUESTIONNAIRE \\
\hline 100 & 120 & 105 & 96 \\
\hline 200 & 150 & 138 & 138 \\
\hline 300 & 150 & 132 & 120 \\
\hline 400 & 180 & 168 & 165 \\
\hline TOTAL & $\mathbf{6 0 0}$ & $\mathbf{5 4 3}$ & $\mathbf{5 1 9}$ \\
\hline
\end{tabular}

Source: Administered Questionnaire

Table 2. Gender of the Respondents

\begin{tabular}{|c|c|c|}
\hline GENDER & FREQUENCY & PERCENTAGE \\
\hline Male & 270 & 52.0 \\
\hline Female & 249 & 48.0 \\
\hline TOTAL & $\mathbf{5 1 9}$ & $\mathbf{1 0 0}$ \\
\hline
\end{tabular}

Source: Administered Questionnaire

Table 3. Respondents' Level of Study

\begin{tabular}{|c|c|c|}
\hline LEVEL & FREQUENCY & PERCENTAGE \\
\hline 100 & 96 & 18.5 \\
\hline 200 & 138 & 26.6 \\
\hline 300 & 120 & 23.1 \\
\hline 400 & 165 & 31.8 \\
\hline TOTAL & $\mathbf{5 1 9}$ & $\mathbf{1 0 0}$ \\
\hline
\end{tabular}

Source: Computed from data collected

Table 4. Cumulative Grade Point Average of Respondents

\begin{tabular}{|c|c|c|}
\hline CGPA & FREQUENCY & PERCENTAGE \\
\hline $1.00-1.49$ & 27 & 5.2 \\
\hline $1.50-2.39$ & 102 & 19.7 \\
\hline $2.40-3.49$ & 174 & 33.5 \\
\hline $3.50-4.49$ & 168 & 32.4 \\
\hline $4.50-5.00$ & 48 & 9.2 \\
\hline TOTAL & $\mathbf{5 1 9}$ & $\mathbf{1 0 0}$ \\
\hline
\end{tabular}

Source: Computed from Administered Questionnaire 
Table 5. Respondents' Participation in Cheating

\begin{tabular}{|c|c|c|c|c|}
\hline S/NO & QUESTIONNAIRE ITEM & $\begin{array}{c}\text { NON-PARI } \\
\text { CIPA- } \\
\text { TION }\end{array}$ & $\begin{array}{c}\text { PARICIP } \\
\text { A- } \\
\text { TION }\end{array}$ & $\begin{array}{c}\text { NO } \\
\text { OPINION }\end{array}$ \\
\hline 1 & Copying other students' work in an examination & $\begin{array}{c}285 \\
(54.90 \%) \\
\end{array}$ & $\begin{array}{c}186 \\
(35.80 \%) \\
\end{array}$ & $\begin{array}{c}48 \\
(9.30 \%) \\
\end{array}$ \\
\hline 2 & $\begin{array}{l}\text { Passing answer scripts to another student in exam. to } \\
\text { copy }\end{array}$ & $\begin{array}{c}429 \\
(82.70 \%) \\
\end{array}$ & $\begin{array}{c}66 \\
(12.70 \%) \\
\end{array}$ & $\begin{array}{c}24 \\
(4.60 \%) \\
\end{array}$ \\
\hline 3 & $\begin{array}{l}\text { Allowing other students to see your answer script in an } \\
\text { exam. }\end{array}$ & $\begin{array}{c}159 \\
(30.64 \%)\end{array}$ & $\begin{array}{c}258 \\
(49.71 \%)\end{array}$ & $\begin{array}{c}102 \\
(19.65 \%)\end{array}$ \\
\hline 4 & $\begin{array}{l}\text { Using unauthorized notes (cribs \& chips) during } \\
\text { examination }\end{array}$ & $\begin{array}{c}462 \\
(89.02 \%)\end{array}$ & $\begin{array}{c}21 \\
(4.04 \%)\end{array}$ & $\begin{array}{c}36 \\
(6.94)\end{array}$ \\
\hline 5 & $\begin{array}{l}\text { Asking for answers to a question from someone during } \\
\text { an exam. }\end{array}$ & $\begin{array}{c}144 \\
(27.75 \%) \\
\end{array}$ & $\begin{array}{c}309 \\
(59.54 \%) \\
\end{array}$ & $\begin{array}{c}66 \\
(12.71 \%) \\
\end{array}$ \\
\hline 6 & $\begin{array}{l}\text { Asking the content of an exam. from someone who has } \\
\text { just taken it }\end{array}$ & $\begin{array}{c}216 \\
(41.62 \%) \\
\end{array}$ & $\begin{array}{c}240 \\
(46.24 \%) \\
\end{array}$ & $\begin{array}{c}631 \\
(12.14 \%) \\
\end{array}$ \\
\hline 7 & $\begin{array}{l}\text { Giving information about the content of an exam. to } \\
\text { someone yet to take the exam. }\end{array}$ & $\begin{array}{c}195 \\
(37.57 \%) \\
\end{array}$ & $\begin{array}{c}210 \\
(40.46 \%) \\
\end{array}$ & $\begin{array}{c}114 \\
(21.94 \%) \\
\end{array}$ \\
\hline 8 & $\begin{array}{l}\text { Visiting a Lecturer in his office to influence your grade } \\
\text { in the exam. }\end{array}$ & $\begin{array}{c}441 \\
(84.97 \%)\end{array}$ & $\begin{array}{c}36 \\
(6.94 \%) \\
\end{array}$ & $\begin{array}{c}42 \\
(8.09 \%) \\
\end{array}$ \\
\hline 9 & $\begin{array}{l}\text { Bringing an impersonator to stand in for you during an } \\
\text { examination }\end{array}$ & $\begin{array}{c}453 \\
(87.28 \%)\end{array}$ & $\begin{array}{c}33 \\
(6.36 \%)\end{array}$ & $\begin{array}{c}33 \\
(6.36 \%)\end{array}$ \\
\hline 10 & $\begin{array}{l}\text { Arranging to sit close to someone in order to copy } \\
\text { answers }\end{array}$ & $\begin{array}{c}285 \\
(54.91 \%)\end{array}$ & $\begin{array}{c}168 \\
32.37 \%)\end{array}$ & $\begin{array}{c}66 \\
(12.72 \%)\end{array}$ \\
\hline 11 & $\begin{array}{l}\text { Bribing or blackmailing a fellow student or a lecturer to } \\
\text { provide an unauthorized assistance }\end{array}$ & $\begin{array}{c}447 \\
(86.13 \%) \\
\end{array}$ & $\begin{array}{c}36 \\
(6.93 \%) \\
\end{array}$ & $\begin{array}{c}36 \\
(6.94 \%) \\
\end{array}$ \\
\hline 12 & Marking attendance for a student who is absent & $\begin{array}{c}153 \\
(29.48 \%) \\
\end{array}$ & $\begin{array}{c}306 \\
(58.96 \%) \\
\end{array}$ & $\begin{array}{c}60 \\
(11.56 \%) \\
\end{array}$ \\
\hline 13 & $\begin{array}{l}\text { Arranging to get answer scripts out of the examiner's } \\
\text { office with or without the examiner's knowledge }\end{array}$ & $\begin{array}{c}453 \\
(87.29 \%) \\
\end{array}$ & $\begin{array}{c}27 \\
(5.20 \%) \\
\end{array}$ & $\begin{array}{c}39 \\
(7.51 \%) \\
\end{array}$ \\
\hline 14 & $\begin{array}{l}\text { Using false excuse to delay taking an examination or test } \\
\text { or turning in of assignment }\end{array}$ & $\begin{array}{c}399 \\
(76.88 \%) \\
\end{array}$ & $\begin{array}{c}57 \\
(10.98 \%) \\
\end{array}$ & $\begin{array}{c}63 \\
(12.14 \%) \\
\end{array}$ \\
\hline
\end{tabular}

Source: Computed by the researcher from the responses collected from students

Table 6. Accounting Undergraduates' Perception of the Reasons for Cheating

\begin{tabular}{|l|c|r|r|}
\hline & $\mathrm{N}$ & Mean & Std. Deviation \\
\hline $\begin{array}{l}\text { Lack of understanding of course material because it is too difficult or } \\
\text { ambiguous }\end{array}$ & 519 & 3.2370 & 1.28335 \\
\hline $\begin{array}{l}\text { Combining full time work with full time study resulting in inadequate period to } \\
\text { study }\end{array}$ & 519 & 3.4162 & 1.23428 \\
\hline Danger of losing ones studentship due to previous low grade & 519 & 3.8092 & 1.21211 \\
\hline $\begin{array}{l}\text { Assigning too much material to be read by the lecturer as if the course is the } \\
\text { only one to be taken by the student }\end{array}$ & 519 & 3.8497 & 1.16662 \\
\hline $\begin{array}{l}\text { The Lecturer doesn't seem to care whether the student learns or understand the } \\
\text { course }\end{array}$ & 519 & 3.5260 & 1.25089 \\
\hline Everyone seems to be cheating without the invigilator caring or noticing & 519 & 2.5434 & 1.30055 \\
\hline The feeling by the student that his cheating does not hurt anyone & 519 & 3.5145 & 1.49653 \\
\hline Pressure to have good grade in order to have better opportunity for employment & 519 & 4.4451 & .76526 \\
\hline $\begin{array}{l}\text { Opportunity created for cheating by a co-student by not covering his/her } \\
\text { answers }\end{array}$ & 519 & 3.3468 & 1.22757 \\
\hline Pressure from a co-student/friend to render assistance during examination & 519 & 3.5318 & 1.22729 \\
\hline Leaving the examination room by the invigilator to phone or talk to someone & 519 & 3.6012 & 1.40902 \\
\hline
\end{tabular}

Source: Analysis of Administered Questionnaire 
Table 7. Chi-square Test Statistics on the Effectiveness of Cheating Deterrent Measure

\begin{tabular}{|l|c|c|c|}
\hline & $\begin{array}{c}\text { CHI-SQUA } \\
\text { RE }\end{array}$ & DF & ASYMP. SIG. \\
\hline $\begin{array}{l}\text { Asking students to put all books and personal belongings } \\
\text { away }\end{array}$ & 106.220 & 4 & .000 \\
\hline $\begin{array}{l}\text { Distributing different forms of the same examination } \\
\text { (coding) to students }\end{array}$ & 50.671 & 4 & .000 \\
\hline Ensuring that there is an empty seat between each student & 65.642 & 4 & .000 \\
\hline Giving all essay-type question & 13.561 & 4 & .009 \\
\hline $\begin{array}{l}\text { Assign pre-numbered seats to students in the examination } \\
\text { hall }\end{array}$ & 20.902 & 4 & .000 \\
\hline $\begin{array}{l}\text { Warning students of the consequences of cheating at the start } \\
\text { of an examination }\end{array}$ & 99.283 & 4 & .000 \\
\hline $\begin{array}{l}\text { Encouraging students to report cheating incidents during } \\
\text { examination }\end{array}$ & 31.769 & 4 & .000 \\
\hline $\begin{array}{l}\text { Invigilators walking up and down the examination room } \\
\text { throughout the examination }\end{array}$ & $\mathrm{I} 02.520$ & 4 & .000 \\
\hline $\begin{array}{l}\text { Making Accounting Students to go through a Course in } \\
\text { Ethics of the Accounting Profession }\end{array}$ & 50.960 & 4 & .000 \\
\hline $\begin{array}{l}\text { Making students to go through disciplinary measures } \\
\text { immediately after cheating and avoiding unnecessary delay }\end{array}$ & 65.873 & 4 & .000 \\
\hline
\end{tabular}

Source: Analysis of Administered Questionnaire 